\title{
The Cadaver as our first Teacher
}

\author{
A. Donna Ropmay
}

Associate Professor, Department of Forensic medicine, North Eastern Indira Gandhi Regional Institute of Health and Medical Sciences, Meghalaya.

Corresponding Author: Dr.A.Donna Ropmay

E-mail:drdonna@rediffmail.com

\section{ABSTRACT}

The present paper looks at the cadavers being a potential and important means of learning for medical students. The word 'cadaver' is derived from the Latin 'cadere' meaning 'to fall', referring to soldiers who died in battle. Therefore, a cadaver is a dead human body used in scientific or medical research. Anatomical dissection is a time-honored part of medical education dating back to the $3^{\text {rd }}$ century BC in Greece.

Key words: cadaver, teaching, medical education.

The journey of a thousand miles begins with the first step, and for me stepping through the hallowed portals of a prestigious medical school way down in southern India was more of disillusionment than enlightenment. During the initial days spent in the anatomy dissection hall, I was shocked to find naked and desiccated bodies of dead human beings. Even though I'm not fainthearted by nature, I felt weak at the knees at the sight around me and the overpowering smell of formalin that filled my nostrils. I stood at a distance from the demonstration table, hesitant to watch and leave alone touch the mummified corpse in front of me. However, as time passed and I delved deeper into the subject of anatomy, I couldn't help but marvel at the wonder and intricacies of the human body with a sense of awe and mystery. I then looked forward to each session with the cadaver to unravel the hitherto unknown secrets of our very form and feature.

The word 'cadaver' is derived from the Latin 'cadere' meaning 'to fall', referring to soldiers who died in battle. Therefore, a cadaver is a dead human body used in scientific or medical research. The term 'dissect' is also derived from Latin 'dissecare' and means 'to cut apart' or 'to separate into pieces' [1]. It refers to dismembering the body of a deceased animal, plant or human to study its anatomical structure. Anatomical dissection is a time-honored part of medical education dating back to the $3^{\text {rd }}$ century BC in Greece. There was a dark period in history when dissection was illegal and offensive to the public. But through the years the practice has gained acceptance worldwide as an indispensable tool for teaching and learning medicine. In the $15^{\text {th }}$ and $16^{\text {th }}$ centuries $\mathrm{AD}$, artists like Leonardo da Vinci and Michelangelo would actually watch live dissections to get a three-dimensional view of the human body which they portrayed in their paintings. During this period, religious authorities in Europe who had earlier disapproved of the practice, began to show a gradual change in their attitude towards cadaveric dissection albeit strictly within the boundaries of European universities [2]. 
Human cadavers have multiples roles within the context of medical training. A hands-on experience by medical students is a must to know the feel of human tissues and organs, the relationship between structures and the concept of innumerable variations within the body. Aspiring surgeons can practice on patients who don't feel pain enabling them to master a surgical skill or procedure without harming anyone. Dentists dissect their heads while physical therapists study the musculoskeletal system [3]. However, cadavers are much more than specimens or dummy patients. The greatest role of a cadaver, which students often overlook, is that of a teacher. In Thailand, a cadaver in the anatomy laboratory is accorded the revered status of 'ajarn yai' or 'great teacher'. There is an attitude of reverence by the students for their highly esteemed teacher as they attribute a social role and position to him/her. He/she is treated as a person and not merely an object [4]. At a college in Mumbai, the cadaveric oath is administered to first year medical undergraduates who pledge to honor the dignity and integrity of the human remains that they are about to work on [5]. On the other hand, trainees at St. John's Medical College start their anatomy dissection classes with a prayer to thank the Almighty for giving them a body to learn from [6]. Anatomy memorial services are held in Mayo Medical College, Rochester, USA to enable students to reflect on the life of the departed souls who facilitated their education [7].

\section{The Johns Hopkins Medical School magazine [8] has this to say: He'll teach you about gross anatomy more than you'll ever learn from books alone. But he'll also teach you how to care. How to detach. How to work as a team. A sense of curiosity and discovery.}

As we routinely go about our duties, we seldom see beyond the immediate mundane tasks that we have to do. We tend to ignore the interests of significant others - both living and deceased. We fail to acknowledge the dead as persons worthy of our time and attention. Let us never forget that every cadaver/corpse is a human anatomical gift without which our teaching and learning experience would be incomplete. In circumstances where bodies have been donated voluntarily for the cause of science, it is all the more appropriate for students to remember that they were once individuals like us with distinctive personalities, thoughts and feelings. That is why it is so very essential to maintain etiquette in the dissection hall and autopsy room at all times. At a university in Taiwan, it is a practice for students to actually visit the families of deceased body donors to express their gratitude for their invaluable contribution to medical science [9]. The same dignity and respect bestowed in life should be given to a person in death as well. Cadavers must be covered when they are not being studied. For the purpose of teaching human anatomy, it is advisable to only expose the part which is being taught, for example the upper limb, thorax or lower limb. Entry to the dissection hall is restricted to Faculty, staff and medical students. A dress code is usually followed by students and instructors alike for the sake of hygiene and safety from biological and chemical agents. The use of personal protective equipment such as aprons, mask, gloves and shoe covers are recommended. Caution while handling sharp instruments is advised. Decorum and good conduct is maintained during classes [10]. Medical teachers are expected to show the way by example and being role models to their pupils on ethical behavior.

My experience in the forensic medical field has taught me to view the corpse not just as an aid to death investigation but as the complete human being he or she was when alive. Although I value the information I glean from every dissection, I realize that it is as important to preserve the dignity, integrity and peace of the deceased and his/her close relatives who are mourning the loss of their loved one. Thus, in our department, we try our best to ensure privacy during autopsy and confidentiality of our findings therein. Students are instructed to observe etiquette while postmortem demonstrations are going on. When the examination is done, the body is washed, dressed, draped and handed over to the next of kin through the police after the necessary legal formalities. 


\section{CONCLUSIONS}

In conclusion, cadavers facilitate a medical student's first exposure to the complexities of the human body. Cadaveric dissection is an essential technique to build up lucid anatomical concepts and relations. The dissection hall provides a direct encounter with the harsh realities of life and death which budding doctors will inevitably face in their future careers. Hence, it is an ideal place to overcome fears and learn how to strike a balance between empathy and detachment in a particular situation. At the end of the day, a physician not only needs sound knowledge and competent skills but also the right attitude to practice one's profession with conscience and dignity. To quote a Latin proverb:

"Let conversation cease. Let laughter flee.

This is the place where death delights to help the living."

\section{REFERENCES}

1. Merriam-Webster I. Merriam-Webster's collegiate dictionary. Springfield: Merriam-Webster; 2003.

2. Ghosh SK. Human cadaveric dissection: a historical account from ancient Greece to the modern era. Anat Cell Biol 2015;48(3):153-69.

3. McCall M. The Secret Lives of Cadavers. National Geographic. July 2016. Available from: https://news.nationalgeographic.com/2016/07/body-donation-cadavers-anatomy-medicaleducation/.

4. Winkelmann A, Güldner FH. Cadavers as teachers: the dissecting room experience in Thailand. BMJ 2004;329(7480):1455-7.

5. Sawant SP, Shaikh S, De Sousa A. Cadaveric Oath in Anatomy - an integral aspect of bioethics training (Brief Report). Global Bioethics Enquiry 2016;4:64-6.

6. Sheriff DS, Sheriff O. The human cadaver: the silent teacher of human anatomy. Indian J Med Ethics. 2010;7:266-8.

7. Wojciech P, Hammer RR, Strauss JD, Heath SG, Zhao KD, Sahota S et al. The Hand That Gives the Rose. Mayo Clin Proc 2011;86(2):139-144.

8. Der Bedrosian J. First-year medical students still rely on cadavers to learn anatomy. John Hopkins Magazine. 2016. Available from: https://hub.jhu.edu/magazine/2016/winter/cadaversanatomy-medical-school/.

9. Kanter SL. A Silent Mentor. Acad Med 2010;85(3):389.

10. Shaikh ST. Cadaver dissection in anatomy: the ethical aspect. Anat Physiol 2015;1:S5-7.

Acknowledgements - I'd like to express my gratitude to Dr. Yookarin Khonglah, Associate Professor of Pathology and Member Secretary, Medical Education Unit, for giving me the opportunity to speak on this topic at the Orientation Programme for MBBS students in October 2017 at NEIGRIHMS, Shillong.

Source of Funding - Nil

Conflict of Interest - Nil 